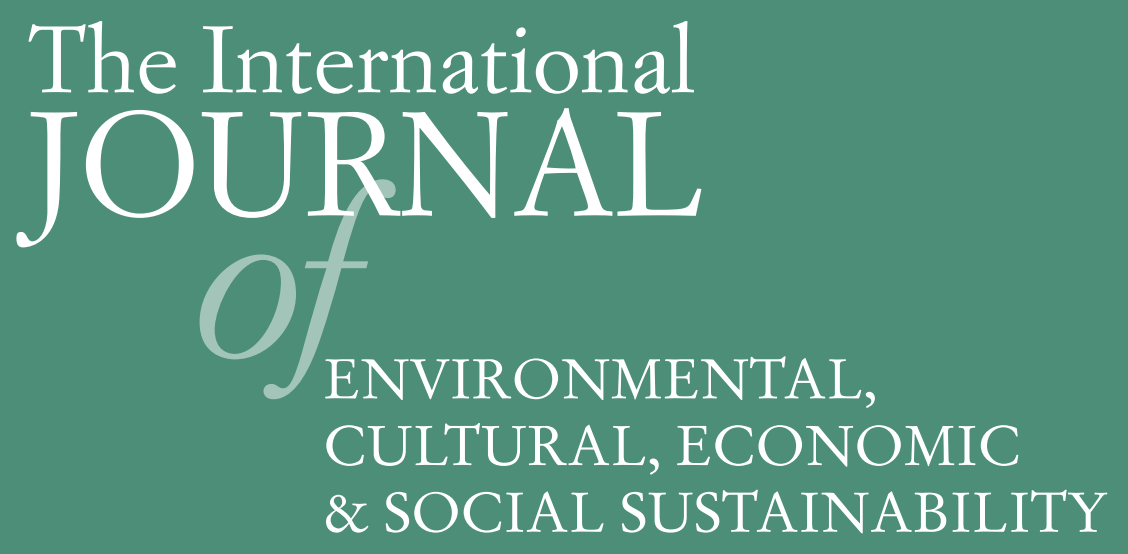

Volume 3, Number 1

The Urban Environment: Agendas and Problems

David Grierson 
THE INTERNATIONAL JOURNAL OF ENVIRONMENTAL, CULTURAL, ECONOMIC AND SOCIAL SUSTAINABILITY

http://www.Sustainability-Journal.com

First published in 2007 in Melbourne, Australia by Common Ground Publishing Pty Ltd www.CommonGroundPublishing.com.

(C) 2007 (individual papers), the author(s)

(c) 2007 (selection and editorial matter) Common Ground

All rights reserved. Apart from fair use for the purposes of study, research, criticism or review as permitted under the Copyright Act (Australia), no part of this work may be reproduced without written permission from the publisher. For permissions and other inquiries, please contact $<\mathrm{cg}$ support@commongroundpublishing.com>.

ISSN: 1832-2077

Publisher Site: http://www.Sustainability-Journal.com

The THE INTERNATIONAL JOURNAL OF ENVIRONMENTAL, CULTURAL, ECONOMIC AND SOCIAL SUSTAINABILITY is a peer refereed journal. Full papers submitted for publication are refereed by Associate Editors through anonymous referee processes.

Typeset in Common Ground Markup Language using CGCreator multichannel typesetting system http://www.CommonGroundSoftware.com. 


\title{
The Urban Environment: Agendas and Problems
}

\author{
David Grierson, University of Strathclyde, UK
}

\begin{abstract}
The United Nations estimate that by 2025 there will be around 5 billion people living in urban areas, more than the total world population 20 years ago. Currently, the developed nations are the most urbanised with, on average around three-quarters of their population living in cities, but this is changing. Increased levels of economic growth, of migration, of population expansion and, in some cases, of unprecedented industrial growth, mean that Asia and Africa will be the regions most radically affected by urban development over the next twenty years. Increasing debate on issues of urban sustainability has led to the consolidation of environmental agendas and the definition of a specific body of problems and policy issues on two levels. The first involves green agenda problems occupying the concerns of many in the developed nations such as global warming, ozone-layer depletion, loss of bio-diversity, deforestation, and the exhaustion of non-renewable resources. For the developing world, however, these global environmental problems are less immediate than the need to resolve acute problems relating to poverty and the so-called brown agenda problems of air and water pollution, inadequate waste management, the lack of basic services and green areas, declining infrastructure, and poor housing conditions, as well as issues of health, crime, violence, and social exclusion. It is now a commonly held belief that the green agenda cannot be addressed until the urgent problems of urban social deprivation and inequalities are resolved. This paper reviews the scale and character of contemporary urbanisation and the rapid growth of cities, particularly within the developing nations, and examines associated implications with respect to the physical arrangement of cities, their resource consumption and their environmental impact.
\end{abstract}

Keywords: Urbanisation, Urban Growth, Environmental Agendas, Equity, Sustainability

\section{Global Cities and "Globalopolis"}

$\mathrm{T}$

TODAY'S CITIES HAVE the potential to be vibrant, sociable, life-enhancing centres of civilisation. They can offer access to creativity, innovation, diversity and information, improved health, higher literacy, and a better quality of life. They can embody the diversity and energy of human pursuits. Offering efficiencies, amenities and opportunities not found elsewhere, they can be in many ways extraordinary engines of economic and social progress. On average people who live in cities will have higher incomes and live, healthier, easier lives than those who live in rural areas. Historically cities have been places where most economic activity has occurred and where great wealth has been generated as a result. They have provided capital, labour and markets for entrepreneurs and innovators at all levels of economic activity. Many, having become centres of modern industry and commerce, of wealth and political power, account for a disproportionate share of a nation's income.

According to some, cities now fulfil a more important role than individual countries in the process of open-ended wealth creation, in large part because of their ability to adapt to change (Jacobs, 1984). And across the planet cities are changing dramatically. We are in the midst of a massive urban transition unprecedented in its scale and celerity. Some of the most powerful cities, in the developed economies of
North America, western Europe and Japan, have become international growth machines of a new global economy that regards every region of the world either as a source of raw materials, a production centre, or an emerging market. Over the last thirty years the pace of growth in these cities has accelerated and, as they get better at what they do their inherent efficiency translates into gains in productivity. Today decisions made in London, New York, and Tokyo today have an impact on jobs, wages and the general economic well-being of places as remote as Santiago in Chile or Chennai in India. The restructuring of the world economy in recent years is one of the most powerful forces in the continuing evolution of cities and has enormous implications for the structure of the global system of cities, the functions cities perform and the nature of social life within them. The most prosperous cities, having successfully managed the conversion from an industrial base to post-industrial employment in finance, services, and information processing, now boast new skylines, converted waterfronts and regenerated residential areas populated by a new urban middle class trained in high technology.

But as an economic, political and socio-cultural phenomenon, globalisation involves an often contradictory and highly mediated process. And there are different and conflicting interpretations regarding its significance for cities and their future. Globalising

THE INTERNATIONAL JOURNAL OF ENVIRONMENTAL, CULTURAL, ECONOMIC AND SOCIAL SUSTAINABILITY, VOLUME 3, NUMBER 1, 2007

http://www.Sustainability-Journal.com, ISSN 1832-2077

(C) Common Ground, David Grierson, All Rights Reserved, Permissions: cg-support@commongroundpublishing.com 
trends can bring enormous prosperity to some cities but they can also give rise to social and economic inequities in others. As urban sociologist Saskia Sassen (1994) has pointed out, the pressures acting upon cities is unevenly spread reflecting an increasingly polarised global society and an emerging new geography of inclusion and exclusion at local, regional and international level. This new geography assumes many forms and operates in many terrains, from the distribution of telecommunication facilities to the structure of the economy and of employment. And even the most powerful cities of the developed economies are blighted by unemployment, poor quality housing stock and as disparities widen among the incomes of high- and low- wage workers a growing underclass is emerging.

Cities, and in particular the large metropolitan centres of the world, have grown more complex and diverse in the context of international economic restructuring, while often becoming more socially divided and physically fragmented. Anonimity becomes a way of life for many. Information theorist Marshall McLuhan wrote in the 1960s about the concept of the "global village" wherein remote inhabitants would learn to respect one another's lifestyle through the medium of television (McLuhan, 1968). But reality has intervened. Real villagers get to know one another by being in close proximity over an extended period of time. When we glimpse the lives of others on today's television footage, it is dans le dépassement. There is little engagement and no sense of belonging. "Globalopolis" has become a more recognizable concept to us these days (Girardet, 1999). In the global marketplace cities have become independent actors that must compete with one another for investment and capital in order to create employment opportunities for their citizens. The success of a city is then a function of its ability to integrate itself in the global society, as much as it is a measure of its ability to develop links to the nation or its immediate hinterland or region. Cities that fail to be assimilated into this international social order can experience economic decline or "distress". 1 Increasingly those who live in a complex urban environment define by reinforced concrete, tinted glass, and high speed living have more in common with one another on the surface than with those who live in rural areas nearby, even although they may not share the same language.

\section{Urban Growth, Urbanisation and the Blurring of Boundaries}

There are more people living in the worlds cities today than were alive a hundred years ago. The developed nations are currently the most urbanised with, on average around three-quarters of their population living in cities. In these countries, the fastest urban growth took place over a century ago and although growth continues today (at less than 1 percent per year) it is at a much slower rate than it has been in previous decades. The majority of the population shift occurring in developed countries now involves movement away from concentrated urban centres to either vast, sprawling metropolitan regions (suburbs) or to smaller cities.

Today growth rates are extremely high in the rapidly industrialising cities of Southeast Asia and Latin America. Cities in these regions offer many advantages over rural villages, having more employment opportunities and superior infrastructure and living conditions. Even so, infrastructure facilities, such as road networks and wastewater treatment plants lag far behind what is needed. The result is among other city-wide problems congested city streets, and mounting air and water pollution. Although many people live in the relative comfort of highly serviced homes huge numbers of poor people live in 'shantytowns', illegal settlements with conditions almost as bad as those in the poorest cities.

Africa and Asia are currently around 40 percent urban but it is in these regions that the most explosive growth is taking place. Cities in these nations will absorb a disproportionate share of urban growth in the decades to come. Africa, currently the least urbanised continent, is experiencing an unprecedented level of urban expansion which will result in more than half of its population living in or around cities by the year 2030. The percentage of population residing in urban areas in Asia will be even higher at around 54 percent (UNPD, 2005). Because of increased levels of economic growth, of migration, of population expansion and, in some cases of unprecedented industrial growth, the bulk of the new urban population in the twenty-first century will be made up of African and Asian people. Asia, in particular is about to go urban in a big way. Its urban population is expected to increase by a staggering I billion people over the next twenty years (UNPD, 2004). There is no historical precedent for increases of this order of magnitude. The rate of urbanisation that results, relative to the level of economic or industrial development that exists, is so excessive that it is often referred to as 'hyper-urbanisation' or 'over-urb-

\footnotetext{
${ }^{1}$ Increasingly over the last thirty years as manufacturing has become dispersed around the globe, some cities which have historically served as manufacturing centres in Europe, North America and Australia are experiencing economic decline as manufacturing, shifts to Asia, South and Central America and elsewhere in the developing world.
} 
anisation'. In these countries the rapid urbanisation now under way will increasingly concentrate both population and economic growth in cities, intensifying the problems of the urban environment.

A principal culmination of five thousand years of human history is a world of giant cities (Dear, 1999). More and more of us are now living in cities of populations greater than 1 million (about the size of Glasgow or Birmingham). By the year 2015, 12 of the world's 15 largest cities will be in Asia; only one New York will be in North America; none will be in Europe.

Kingsley Davis (1965) presented a clear framework for understanding population dynamics and urban growth, defining the process of 'urbanisation' as, "the switch from a spread out pattern of human settlement to one of concentration in urban centres". It is clear that, although this process has occurred throughout the world at varying rates during all of human history, our own particular place in the history of the city is unique. Since the middle of the twentieth century the population of the world's cities has soared from 200 million to more than 3 billion. This growth reached a significant stage in 2005 when, for the first time in human history, around one half of the global population, an estimated 3.3 billion, was deemed to live in and around cities (UNPD, 2005). Predictions suggest that it will be well into the twenty-first century before urban population significantly slows down (Devas and Rakodi, 1993).

Davis had stressed the impact of 'excessive' population growth on world urbanisation and predicting that the less developed countries would eventually be unable to sustain their populations. He concluded that there would be an end to urbanisation but not necessarily to absolute population growth, economic development, the physical size of cities, or the absolute number they might contain. The "end of urbanisation", he said, occurs in industrialised countries when there is no longer a large enough rural population to create a significant migration to cities, or the suburban population begins to increase as fast as the urban population.

Davis, however, recognised that pushing the definition of 'urban' away from the notion of dense settlement towards sprawl means, in a sense, that the slowing down of urbanisation is more apparent than real; in effect an increasing number of urbanites simply become suburbanised. In this way, he accurately predicted that the boundaries of urban places within developed countries would become blurred; as a society becomes advanced enough to be highly urbanised the whole "concept of urbanisation becomes ambiguous" (Davis, 1965).

\section{A Deteriorating Environment}

The deleterious impact of the process of urbanisation on the environment is unambiguous. Although the world has witnessed economic and social progress during recent decades economic and social gains have been unequally distributed and there are significant environmental implications inherent in these changes. As cities compete with one another to attract manufacturing and other services, the bargaining chips are sometimes cheap labour and lax environmental concerns. Globalisation and economic reforms may well lead us to greater environmental deterioration (Sivaramakrishnan, 1996). The struggle to achieve an environmentally sustainable global economy will be won or lost in the world's cities but the urban environment is now firmly driving the environmental crisis generally (UN Habitat II, 1996). Although they take up just 2 percent of the Earth's surface, cities consume most of the world's natural resources and cause most of the pollution and waste. Particularly in the cities of the developed world excessive consumption of natural resources is dramatically reducing the global resource base and is leading to urban health problems on an unprecedented scale.

Along with the benefits of urbanisation have come environmental and social problems of staggering proportions. Environmental problems are most severe in those developing world cities experiencing rapid economic growth. Many people in these cities live in life threatening conditions. In 1995 polluted air in 36 cities in India alone killed some 52,000 people, representing a 28 percent increase from the early 1990s. Today more than 600 million people in the undeveloped world are living in cities without adequate shelter. At least 220 million of the urban poor lack any access to clean drinking water and more than 420 million do not have the simplest toilet. Between one and two thirds of the solid waste generated in these cities is left to pile up in streets and drains, contributing to flooding and the spread of disease, adding to an enormous toll of largely preventable deaths. Around 1.1 billion live in urban areas where air pollution exceeds health limits.

Almost all of global urban growth over the coming decades will occur in the developing world, where it is already proving almost impossible to create the services and infrastructure needed to support the swelling urban masses and expand agricultural land and capital fast enough to accommodate the huge natural population increase in rural areas. There is no historical precedent for changes of this scale and speed and there is little guidance as to the magnitude of problems that such growth might pose. Large cities of the developing countries lack both the human and technical resources necessary to deal with the full range of urban development needs. Rapid population 
growth has increased the tendency of cities in developing countries to outgrow the resources of the economies they are supposed to nourish and support. The traditional range of public services, utilities and welfare taken for granted in cities of developed countries are simply not generally available to the inhabitants of most of the cities of the developing countries, which suffer from a lack of finance, infrastructure and skills at all levels.

\section{Two Agendas}

Increasing debate has led to the consolidation of urban environmental agendas and the definition of a specific body of problems and policy issues. There is very real concern for the sustainability of cities on two levels. The first is global and involves, what is referred to as the green agenda problems such as global warming, ozone-layer depletion, loss of biodiversity, deforestation, and the exhaustion of nonrenewable resources. Cities of the world affect not just the health of their own citizens but the health of the planet. It is clear that the world's cities will not prosper if collectively their impact on the planet is unsustainable. Governments and environmentalist groups from the advanced nations considered the green agenda problems to be a priority, so the "Earth Summit" in 1992 focused on these issues. But, for the developing world, global environmental problems are less critical than the need to resolve the immediate and acute problems relating to poverty and the so-called brown agenda problems of air and water pollution, inadequate waste management, the lack of basic services and green areas, declining infrastructure, and poor housing conditions, as well as issues of health, crime, violence, and social exclusion. Among developing countries it is a commonly held belief in that the green agenda cannot be addressed until the urgent problems of urban social deprivation and inequalities are resolved (Stren et al, 1992).

While there is no clear dividing line between the two agendas, they can be distinguished along a number of different dimensions: spatial, temporal and political. The brown agenda addresses those environmental burdens more typically associated with poverty and issues that are more local and immediate; generally affecting urban inhabitants in today's cities. While the green agenda addresses environmental burdens more typically associated with affluence and issues that are more dispersed, delayed and that will largely affect future generations. Both carry conflicts and complementarities. Aware of the mismatch between the global green agenda and the problems confronting cities, researchers and non-governmental organisations (NGOs) have been advocating a renewed focus on the brown agenda and particularly the problems of pollution, poverty, and environment- al hazards in cities today. The argument is not for less attention to be paid to global concerns but for recognition that urban and global concerns are interrelated and must both be addressed.

\section{Towards Sustainability}

The transition to an urbanized world continues to have a profound effect on the physical arrangement of cities, their resource consumption, and their environmental impact. Throughout the last decade a cluster of United Nations conferences and conventions, beginning with the Earth Summit in 1992, have discussed the continuing deterioration of the ecosystems on which we depend for our well-being, and identified a common need to develop a global partnership for sustainable development. Recognizing that conditions in the world's cities, particularly those in undeveloped nations, had reached crisis point, the Habitat II (the 'City Summit') Conference, held in Istanbul in 1996, concluded with a global call to action to improve the quality of life within human settlements in cities around the world. Paragraph 4 of The Habitat Agenda: Istanbul Declaration on Human Settlements identified a need to confront problems such as:

- unsustainable consumption and production patterns, particularly in industrialized countries;

- unsustainable population changes, including changes in structure and distribution, giving priority consideration to the tendency towards excessive population concentration;

- homelessness;

- increasing poverty;

- unemployment;

- social exclusion;

- family instability;

- inadequate resources;

- lack of basic infrastructure and services;

- lack of adequate planning;

- growing insecurity and violence;

- environmental degradation;

- increased vulnerability to disasters.

A pro-growth development paradigm has underpinned the formation of the built environment throughout the 20th century. The Club of Rome's Limits to Growth report (Meadows, Meadows, Randers, Behrens, 1972) highlighted an inherent fundamental flaw, pointing out that global growth in population numbers, resource use, waste production, and pollution is exponential. While this kind of growth displays a gentle and gradual curve for a long time it rapidly shoots up in a very short period of time. What might seem like a manageable rate of resource use and waste disposal can quickly result in dangerously low levels of available resources and 
dangerously high levels of pollution. Environmentalists now question whether the rapid growth of cities in recent years can be sustained. They argue that in order that the quality of life of their inhabitants be maintained, let alone enhanced, the aggregate impact of cities on the environment - a product of the relationship between population, per capita consumption or economic activity, and energy/material flow per unit - must be radically reduced.

Sustainability involves a move from a current condition of unsustainable activity towards a process of improvement and increased quality. Essentially the term is used to indicate a change of attitude towards prioritizing ways of life that are in balance with the current renewable resources of the ecosystem and the biosphere. How we might better understand the nature of this balance and its relationship to the built and natural environments, thus helping to inform decision-making at various levels, is the subject of ongoing research. Although we are unclear about how much damage has already been inflicted on the biosphere a precautionary approach is proposed as a practical way forward. In the face of inherent uncertainty, risk is not an appropriate approach. Failure to maintain a viable biosphere will be catastrophic and irreversible.

The widespread interest in theories, ethics, and practice concerning sustainability indicates an increasing concern about the adverse impacts that conventional models of development have had on the environment, in both the developed and undeveloped parts of the world. Today, as urban environmental problems have been brought more sharply into focus, sustainable development is being described as a fundamental goal. The term has been used in recent years to catalyze debate concerning the relationship between economic growth and the natural resource base on which it depends. It was provided a global definition by the Brundtland Commission report (World Commission on Environment and Development, 1987) as development that meets the needs of the present without compromising the ability of future generations to meet their own needs. The definition implies that a balance can be found between how much development we are able to make while still preserving the environment to the extent that it can sustain an acceptable quality of human life in the future. It is not about the environment per se but involves a more complex, holistic, and systemic approach that mediates between social, economic and environmental processes and cuts across disciplines and subject areas. By suggesting that environmental protection and continuing economic growth can be seen as mutually compatible, it attempts to displace the limits to growth argument.

Although often criticized as being vague and even contradictory, the concept of sustainable develop- ment has, in recent years, begun to achieve political priority status among government institutions seeking a planned response to urban environmental problems. Alternative ways of re-thinking and reforming the built environment within a rapidly urbanizing world are now being considered. Within the academic and policy literature emerging around the notion of sustainable cities, a number of different models have been developed which represent different views of how such environments might be realized (Haughton $\&$ Hunter, 1994). Some advocate re-designing the physical fabric of the city in order to improve resource efficiency and bring about more self-reliant settlements. This approach involves the frugal use of energy and natural resources while working within the carrying capacity of the local region. It also implies that the ecological footprint and energy budget for human settlements are vastly reduced. A move towards a smaller, more compact settlement pattern interspersed with productive areas for collecting energy, to grow crops for food, fiber and energy, and recycle wastes has been suggested as the way forward. The compact city idea is now being promoted as a major component of the various strategies emerging to tackle these problems (Breheny, 1996). The rationale for its implementation lies in a set of benefits that are seen as the outcome of more compact urban forms in which travel distances are reduced lessening fuel emissions, rural land is saved from development, local facilities are supported, and local areas become more autonomous.

It is clear that many of the environmental problems we currently face are directly or indirectly related to issues of urban lifestyles and consumption patterns, which have far-reaching and long-term effects, not only within the city's own boundaries, but on the entire surrounding region. The collective term used to define these relationships refers to the ecological footprint of cities. Today the effects of urban activities have, in many cases, outweighed the relative advantages of agglomeration and centrality that they otherwise offer, and the ecological footprints of existing cities cover almost the entire planet. Meeting the needs of the current global population in the same way that those of Western urban inhabitants are currently met would require a few more planets with the same resources as Earth (Wackernagel and Rees, 1996). As urban populations and cities expand, competition for these dwindling areas of resource is growing while, simultaneously, areas of fertile land and rain forests are rapidly disappearing. As a result, throughout the underdeveloped world populations are being forced onto marginal lands, generally ill suited to agriculture due to adverse climatic and topographical conditions. Urban systems are undermining the planet's health and failing to provide decent living conditions for millions of people. Given the 
clear physical limitations urban ecological footprints should themselves have defined limits. But, in the first instance, they need be reduced from their current levels.

\section{Planning for Sustainability}

The brown agenda presents a renewed challenge to the planning and management of cities. While Breheny (1996) highlights the lack of any cogent debate on issues of urban sustainability, a growing body of work now exists which examines and promotes the idea of the 'sustainable city' or 'sustainable urban development' in a general sense (see, for example, Stren et al 1992; Haughton \& Hunter, 1994; Smith et al., 1998), in relation to particular issues like energy consumption, pollution, and transportation (for example, Nijkamp \& Perrels, 1994; World Resource Institute [WRI], 1996); Girardet (1999), and with regard to urban form (for example, Breheny, 1992; Calthorpe, 1993; Jenks et al. 1996; Frey, 1999).

Urban sustainability requires that we see urban systems as ecosystems, where humans through their actions, have produced changes that have thrown the global ecosystems off balance. The challenge then is to establish what actions need to be taken to counter the negative effects of human activity and maintain equilibrium within the parameters of sustainability. A city's use of resources has been measured in terms of its 'ecological footprint' - an area geographically dispersed throughout the world and much larger than the physical boundary of the city itself (Wackernagel and Rees, 1996). According to Girardet (1992) the key to the reduction of urban ecological footprints lies in cities adopting a "circular metabolism", where consumption is reduced by implementing efficiencies and where re-use of resources is maximised. Material recycling, waste reduction, energy conservation and the use of renewable energy sources are approaches, which are recognised as part of this strategy. Girardet argues that, since the majority of current production and consumption takes place in cities, the current "linear metabolism" involving processes that involve high levels of production and consumption must be replaced by those that aim at a circular system of use and re-use. Such a process would increase a city's efficiency and lessen its environmental impact.

Following Girardet, Rogers (1997) believes that to achieve a circular metabolism cities must be planned to manage their use of resources. In order to move towards this he argues that we need to develop a new from of "comprehensive holistic urban planning" that will signal a "new and dynamic equilibrium between society, cities and nature". He describes his approach to urban sustainability as a rein- terpretation and reinvention of the 'dense city' model which would adopt modern technologies to redefine the social advantages of proximity. Rogers' main argument is presented in favour of "compact mixed-use nodes" forming "lively sustainable neighbourhoods". His 'sustainable city' would consist of as a series of inter-linked sustainable communities consisting of "overlapping domains", of balanced "multi-activity, dense urban structures", of "pedestrianisation" and "three-dimensional planning".

\section{The Compact City?}

The contemporary debate on sustainable urban form took off in the 1980s when it was acknowledged that city planning had a significant role to play in the promotion of sustainable development. Since then the environmental imperative has revived the idea that the planning of cities is a legitimate, indeed crucial, practice. As the debate has focused on environmental sustainability - and in particular the issues of global warming and urban sprawl - the 'centrist' view of urban compaction has gained ascendancy over the 'decentrist' view.

Whilst the arguments are far from resolved in favour of urban compaction this has become, by far, the most popular policy approach, endorsed by, for example, the European Commission's 1990 Green Paper on the Urban Environment. The Green Paper called for a return to the 'compact city' along the lines of the densely developed cores of many historic European towns and cities (Dantzig and Saaty, 1973). The high population densities in such places are deemed to encourage social mix and interaction and make them good places to live and work. Arguments for the compact city form suggest that it can address the physical and social urban environmental problems within the brown agenda. As a result of the containment of high population densities within a compact city form existing infrastructure and previously developed land can be re-used while existing urban areas can be regenerated and revitalised thus allowing the surrounding countryside to be conserved. The promotion of affordable public transport means that the daily travel needs of the majority of the urban population can be met without widespread use of the car, levels of traffic related pollution are decreased along with the risk of death and injury in road traffic accidents, and as congestion is alleviated accessibility and mobility can improve. High population densities mean that a policy of mixed land-use becomes viable, travel distances are reduced, cycling and walking become the most energy efficient ways of moving around, and so car-dependency is further reduced. Less car-use means a reduction in the most rapidly growing source of "greenhouse gas" emis- 
sions - chemicals that have the potential to contribute to global warming such as carbon dioxide, chlorofluorocarbons (CFCs), nitrous oxide, and carbon monoxide. It also means a reduction in energy demand leading to a lowering in the level of consumption of non-renewable fossil fuels, and improved air quality \& consequently better health.

A denser urban fabric would increase opportunities for economies of scale allowing for energy savings due to agglomeration, the introduction of collective 'soft energy' systems (solar, wind, water power, etc.) and renewable electricity supply, the promotion of community based material recycling policies - glass, metal, paper, and some plastics, the promotion of large-scale biological waste treatments, and further reductions in levels of pollution associated with an overall reduction in energy consumption.

There are several arguments opposed to the compact city idea. There are those who argue that it ignores the fondness for suburban living; that telecommunication advances contradict the concept; that rural communities could be neglected; that there could be a loss of amenity and privacy; and that there is, in any case, a lot of uncertainty concerning future patterns of population growth and dispersal. David Harvey, for example, raises the general concern about the activities of planners who put physical things, like urban form, before social processes. This leads to failed attempts at social engineering based on changing the physical fabric of cities but concedes that "high density urbanised living and inspired forms of urban design are the only paths to a more ecologically sensitive form of civilisation in the twenty first century" (Harvey, 1996).

Globalopolis, the dominance of urban sprawl, and the deteriorating urban environment, seem to be demanding big solutions or 'metanarratives'. The postBrundtland (1987) political urgency of the sustainable city debate has taken hold in recent years. As countries' commitment to the sustainable development idea has increased throughout the last twenty years, governments are keen to deliver major environmental improvements (in line with both the green and brown agendas) and are looking to planning systems to achieve greater urban compaction. Eager to meet international environmental obligations, politicians are pressing on with specific 'centrist' policies, before the research community have been able to confirm what effect such policies will have. Even although questions remain on whether the compact city can deliver sustainability, the focus of the debate is now on technical questions on how to achieve compaction. There is general consensus that a city must be sustainable not only in terms of how it functions economically and socially but also environmentally. In searching for sustainable urban form and structure the need for a holistic approach is now largely accepted. Considerable consensus exists in developed nations around many policy goals, such as improving energy conservation, reducing car dependence and in a shift towards more compact city forms, with higher residential densities and mixed land uses (Haughton, 1999).

The centrist view is now being promoted both academically and politically and areas of difference over policy measures tend to be ones of degree rather than fundamental disagreement. Questions remain, however, as to whether the compact city will deliver the kind of environmental gains that our governments are now obliged to achieve and the broader questions surrounding the social, economic, and cultural viability of transforming existing cities into more compact versions remain. It seems unthinkable that, as profound lifestyle changes characterise the early years of the twenty-first century, that one model will offer a solution to the complex and multivalent problems of accommodating sustainable societies. It is more likely that the search for sustainable urban form will be better redirected to the search for a number of different approaches, models and forms that can respond to the variety of existing settlement patterns and contexts.

\section{References}

Breheny, M. "Centrists, Decentrists and Compromisers: Views on the Future of Urban Form" in ed. Jencks, M. The Compact City: A Sustainable Urban Form? London: E \& FN Spon, 1996 Calthorpe, P. The Next American Metropolis:

Ecology, Community and the American Dream. New York: Princeton Architectural Press, 1993

Dantzig, G. and Saaty, T. Compact City: A Plan for a Liveable Urban Environment. San Francisco: Freeman, 1973.

Davis, K. "The Urbanization of the Human Population" in Scientific American. (September, 1965) Dear, M.J. The Postmodern Urban Condition. Massachusettes: Blackwell, 1999.

Devas, N. and Rakodi, C. (eds.), "The Urban Challenge" in Managing Fast Growing Cities. London: Longman Group, 1993.

Frey, H. Designing the City: Towards a More Sustainable Urban Form. London: E \&FN Spon, 1999.

Girardet, H. The Gaia Atlas of Cities. London: Gaia Books, 1992.

Harvey, D. "Cities or urbanization" in Cit.y (1996): 1/2

Haughton, G. and Hunter, C. Sustainable Cities. London: Jessica Kingsley Publishers, 1994

Haughton, G. "Searching for the Sustainable City: Competing Philosophical Rationales and Processes of 'Ideological Capture' in Adelaide, South Australia" in Urban Studies (1999): 36/11

Jacobs, J. Cities and the Wealth of Nations. New York: Random House, 1984.

McLuhan. M. et al. War and Peace in the Global Village. San Francisico: Hardwired, 1968. 
Meadows, D. H. et al, The Limits to Growth. London: Earth Island, 1972.

Nijkamp, P. and Perrels, A. Sustainable Cities in Europe. London: Earthscan Publications, 1994

Rogers, R. Cities for a Small Planet. London: Faber and Faber, 1997.

Sassen, S. Cities in the World Economy. California: Pine Forge Press, 1994.

Sivaramakrishnan, K. C. "Urban Governance: Changing Realities" in Preparing for the Urban Future. Washington DC: Woodrow Wilson Centre Press, 1996.

Smith, M. et al. Greening of the Built Environment. London: Earthscan, 1998.

Stren, R. White, R. and Whitney J. (eds.), Sustainable Cities: Urbanization and the Environment in International Perspective. Colorado: Westview Press, 1992.

United Nations Conference on Human Settlements, The Habitat Agenda: Istanbul Declaration on Human Settlements. UN Habitat II: Istanbul, 1996.

United Nations Population Division, World Population Prospects: The 2004Revision Analytical Report. New York: United Nations Publications, 2004.

United Nations Population Division, World Urbanization Prospects: The 2005 Revision Analytical Report. New York: United Nations Publications, 2005.

Wackernagel, M. and Rees, W. Our Ecological Footprint: reducing Human Impact on the Earth. British Columbia: New Society Publishers, 1996.

World Resource Institute (WRI), World Resources 1994 - 1995. New York: Oxford University Press, 1995.

\section{About the Author}

Dr. David Grierson

Dr Grierson is both an architect and an academic. He is a member of the Architects Registration Board (ARB) and the Higher Education Academy (HEA). 


\section{THE INTERNATIONAL JOURNAL OF ENVIRONMENTAL, CULTURAL, ECONOMIC AND SOCIAL SUSTAINABILITY}

\section{EDITORS}

Amareswar Galla, Australian National University, Australia.

Mary Kalantzis, University of Illinois, Urbana-Champaign, USA.

\section{EDITORIAL ADVISORY BOARD}

Dang Van Bai, Ministry of Culture and Information, Vietnam.

Diane Bell, The George Washington University, Washington DC, USA.

Richard M. Clugston, Center for the Respect of Life and the Environment, and University Leaders for a Sustainable Future, Washington DC, USA.

Bill Cope, University of Illinois, Urbana-Champaign, USA.

John Dryzek, Australian National University, Canberra, Australia.

Robyn Eckersley, University of Melbourne, Australia.

Steven Engelsman, Rijksmuseum voor Volkenkunde, The Netherlands.

John Fien, RMIT University, Melbourne, Australia.

Steve Hemnett, University of South Australia, Australia.

Paul James, RMIT University, Melbourne, Australia.

Lily Kong, National University of Singapore, Singapore.

Thangavelu Vasantha Kumaran, University of Madras, India.

Jim McAllister, Central Queensland University, Australia.

Helena Norberg-Hodge, The International Society for Ecology and Culture (ISEC).

Peter Phipps, RMIT University, Melbourne, Australia.

Koteswara Prasad, University of Madras, India.

Judy Spokes, Cultural Development Network, Melbourne, Australia.

Manfred Steger, Illinois State University, USA and RMIT University, Australia.

David Wood, University of Waterloo, Canada.

Lyuba Zarsky, RMIT University, Australia, and Tufts University, USA.

Please visit the Journal website at http://www.Sustainability-Journal.com for further information:

- ABOUT the Journal including Scope and Concerns, Editors, Advisory Board, Associate Editors and Journal Profile

- FOR AUTHORS including Publishing Policy, Submission Guidelines, Peer Review Process and Publishing Agreement

\section{SUBSCRIPTIONS}

The Journal offers individual and institutional subscriptions. For further information please visit http://ijs.cgpublisher.com/subscriptions.html. Inquiries can be directed to subscriptions@,commongroundpublishing.com

INQUIRIES

Email: cg-support@commongroundpublishing.com 